\title{
Legitimation Strategies of Corporate Elites in the Field of Labor Regulation: Changing Responses to Global Framework Agreements
}

\author{
Markus Helfen \\ Freie Universität Berlin \\ School of Business and Economics \\ Management Department \\ Boltzmannstr. 20 \\ D-14195 Berlin, Germany \\ Phone: +49 3083854175 \\ Fax: +493083856808 \\ e-Mail: markus.helfen@fu-berlin.de \\ Elke Schüßler \\ Freie Universität Berlin \\ School of Business and Economics \\ Management Department \\ Boltzmannstr. 20 \\ D-14195 Berlin, Germany \\ Phone: +49 3083856807 \\ Fax: +493083856808 \\ e-Mail: elke.schuessler@fu-berlin.de \\ Sebastian Botzem \\ University of Bremen \\ Institute for Intercultural and International Studies (InIIS) \\ Mary-Somerville-Straße 7 \\ D-28359 Bremen, Germany \\ Phone: +49 422121867465 \\ Fax: + 49422121867491 \\ e-Mail: sebastian.botzem@iniis.uni-bremen.de
}

Acknowledgements: We thank the editors and especially Sigrid Quack for invaluable comments regarding the development of this paper.

Pre-Print Version, quote as Helfen, M./Schüßler, E./Botzem, S. (2015): Legitimation strategies of corporate elites in transnational labor regulation: Changing responses to Global

Framework Agreements. Research in the Sociology of Organizations 43: 243-268. 


\begin{abstract}
Corporate elites are increasingly held responsible for issues of sustainability including working conditions and workers' rights in global production networks. We still know relatively little about how they respond to concrete stakeholder initiatives aiming to restrict corporate voluntarism through transnational regulation. In this chapter we report comparative findings on corporate legitimation strategies in response to requests by labor representatives to sign Global Framework Agreements (GFAs). These agreements are intended to hold multinational corporations (MNCs) accountable for the implementation of core labor standards across their supply chains. We propose to broaden management-focused analyses of corporate legitimation strategies by applying a field-oriented perspective that considers the embeddedness of management in a broader web of strategic activity and variable opportunity structures. Our findings suggest that legitimation strategies are developed dynamically along with the rules, positions, and understandings developing around specific regulatory issues in sequences of interactions between elites and challenging groups.
\end{abstract}




\section{Introduction}

As indicated by the proliferation of terms such as perception and impression management, public affairs management, or corporate social responsibility, legitimizing corporate activities vis-à-vis external expectations has become an important management activity that goes beyond traditional public relations (e.g. Kostova \& Zaheer, 1999; Strike, Gao, \& Bansal, 2006). Multinational corporations (MNCs) in particular are increasingly scrutinized by civil society groups and non-governmental organizations (NGOs) criticizing the violation of labor rights or environmental standards. Given that activities of MNCs extend across national jurisdictions, corporate elites are confronted by multiple efforts to regulate their behavior on a transnational level (Waddock, 2008). And yet, in the absence of a statelike authority, corporations are also called upon to participate in creating, shaping and enforcing emerging environmental and social regulations (Scherer and Palazzo, 2011).

On the one hand, corporate elites try to exploit the existence of multiple regulatory initiatives by avoiding any binding regulation or shifting towards a forum in which rules are set that are in line with their interests (Quack, 2013). On the other hand, corporate elites cannot take their influence within organizational domains or on regulatory policies for granted because different actors, among them even small NGOs and social movements, can raise challenges that make transnational fields contested and fluid (Djelic \& Sahlin-Andersson, 2006; Djelic \& Quack, 2008). Scherer and colleagues (2013) have recently argued that in complex global environments corporations use three different, and at times contradictory, legitimation strategies: adaptation, manipulation, and moral reasoning. In so doing, they seek to account for heterogeneity and dynamism in stakeholder expectations, appeasing or coopting challengers while preserving as much autonomy as possible. While Scherer and colleagues (2013) discuss how organizations intend to cope with the paradoxical tensions posed by such an approach, they do not study the dynamic interplay and resultant shift in the corporate elites’ legitimation strategies over time within a specific field of regulation. 
In this paper, we address this gap by studying how corporate elites dynamically adjust their legitimation strategies in response to legitimacy threats in the field of transnational labor regulation emerging around Global Framework Agreements (GFAs). GFAs are companybased agreements codifying MNCs’ commitment to comply with core labor standards defined by the International Labor Organization (ILO) across their supply chains. They are negotiated and signed by Global Union Federations (GUFs) and top management representatives. As such, they can be regarded as a joint attempt of MNCs and civil society actors - specifically trade unions and their global federations - to regulate labor relations transnationally and to monitor compliance. Similar to other attempts regulating transnational sustainability issues (Palazzo \& Scherer, 2006), the actual impact of such negotiated agreements for workers at the bottom of the pyramid is still unclear. However, the range of elite reactions to GFAs indicate that such agreements have the potential to effectively challenge corporate elites' positions in the field of labor regulation. GFAs thus provide a rich empirical setting in which to analyze how legitimation strategies of corporate elites evolve through the interaction with challenging actors in contested transnational regulatory fields.

In only two cases of our sample of 12 MNCs engaging in GFA negotiations corporate elites changed their legitimation strategy and shifted from initial resistance towards engagement in moral reasoning with corporate challengers. In the other cases, MNCs only marginally changed their legitimation strategies from resistance towards selective adaptation of GFAs or manipulation of the agreements in order to avoid an actual change in behavior. The extent of change and type of legitimation strategy adopted depended on the enactment of opportunity structures provided by transnational institutional heterogeneity, established patterns of national labor relations, and specific actor constellations. Thus, our study suggests that legitimation strategies need to be understood as developing out of a process of contestation embedded in and impacting on the rules, positions and understandings around a substantive domain of regulation. 


\section{Theoretical Framework}

\subsection{Corporate Elites in Transnational Regulatory Fields}

Transnational regulatory arrangements have emerged in different contexts, ranging from the realm of professional services (e.g. Suddaby et al., 2007) and financial markets (e.g. Mayntz, 2012) to that of various social and environmental standards (e.g. Overdevest, 2010). They tend to be driven predominantly by private actors such as corporations and NGOs (e.g. Bartley, 2005) but are also impacted by public actors, i.e. governments and international organizations (e.g. Schüßler et al., 2014). In any case, transnational regulation always involves negotiations and struggles among a diverse set of actors with conflicting interests, thereby leading to reconfigurations of rule-setting authority between public and private actors (Botzem and Hofmann, 2010). Central questions in researching transnational regulation thus revolve around who is able to claim and provide legitimacy for rule-setting and monitoring, as well as how other actors in the field respond to these activities (Dezalay and Garth, 2008; Quack, 2010; Zürn, 2004).

Although we know less about the power resources of corporate elites on a transnational level, we know from national contexts that corporate leaders commonly have command over financial and often social capital that allows them to influence important policy decisions (Mills, 1956; Useem, 1984). As recent evidence shows, transnational elites are firmly embedded in national arenas (Carroll, 2009). Such power is often considered structural, based as it is on connections to elite networks and public agencies (e.g. Barley, 2007; 2010; Davis, 1991; Davis and Greve, 1997; Davis and Mizruchi, 1999; Mizruchi, 2004, Pfeffer and Salancik, 2003). Equally, institutions like corporate law, property rights, professions, or social customs (DiMaggio and Powell, 1991; Hensmans, 2003; Lawrence, 2008) are important elements of national elites' power resources. At the transnational level, elite studies using structural network analyses have identified similar groups and overlaps, mainly between European and North American corporations given shared activities on 
transnational boards (Carroll and Sapinski, 2010). While these studies shed some light on the potential of corporate elites to influence transnational regulatory processes, they largely neglect contestation dynamics in which management practices are being challenged by outside actors.

A field-level approach is useful to capture these dynamics because it recognizes the fluidity of elites in today's globalized, post-industrial society in which legitimate influence is the outcome of specific interaction patterns in complex webs of relationships (Bernstein, 2011; Malets \& Quack, 2013; Quack, 2013; Harvey \& Maclean, 2010). Regulatory fields typically form around a contested issue and evolve as actors struggle over the rules, positions, and understandings dominating the field (Hardy \& Phillips, 1998; Hoffman, 1999; Levy, 2008; Rao et al., 2000). Business actors participate in these fields in various guises, so we define corporate elites broadly as going beyond the directors of the world's largest 500 corporations who sit on at least two G500 directorates (cf. Carroll, 2009) to also include the supportive stratum of managers occupying positions below the peak level (cf. Kerr \& Robinson, 2012), as well as a host of professional business consultants, policy advisors and representatives from business associations involved in shaping emerging regulations (Zald \& Lounsbury, 2010).

Corporate elites are regularly drawn into contest over the rules, positions, and understandings around specific regulatory issues by challengers in the form of advocacy coalitions and social movements (e.g. Lounsbury et al., 2003; McAdam and Scott, 2005). Such "strategic action fields" are characterized by dynamism and change, because actors "make moves and other actors have to interpret them, consider their options, and act. Actors who are both more and less powerful are constantly making adjustments to the conditions in the field given their position and the actions of others.” (Fligstein and McAdam, 2011: 5). Yet, despite this dynamic conception of strategic agency, actors' positions are still often considered as relatively static, with challengers thought to populate niches in the field that 
ordinarily wield little influence (Fligstein and McAdam, 2011: 6). Both corporate elites and challenging groups, however, need to socially construct and fight for their positions in a regulatory arena through the use and dynamic adjustment of legitimation strategies (Dezalay \& Garth, 2010: 117).

\subsection{Towards a Field-Oriented Analysis of Legitimation Strategies}

Legitimacy can be understood as a "generalized perception or assumption that the actions of an entity are desirable, proper, or appropriate within some socially constructed system of norms, values, beliefs, and definitions” (Suchman, 1995: 574). As such, legitimacy is important for all organizations, because it allows them to acquire material and human resources necessary to survive (Aldrich \& Fiol, 1994), grow (Khaire, 2010), and change (Suddaby \& Greenwood, 2005). Much of the research on organizational legitimation strategies has focused on the discursive, rhetorical efforts of organizations to rationalize, normalize, or theorize their actions vis-à-vis opponents and the wider public. Corporations, for instance, use legitimation strategies to gain acceptance for organizational changes such as restructuring and downsizing (e.g. Vaara et al., 2006; Erkama \& Vaara, 2010). However, legitimacy not only depends on managing public perception, it also rests on the underlying socially constructed system of norms and formal regulations against which such perceptions of legitimacy are defined and challenged. Legitimacy is thus closely tied to the hegemony of those who shape rule systems and demand rule following (Ashforth \& Gibbs, 1990; Pfeffer \& Salancik, 2003).

The groundwork for research on corporate legitimation strategies has been laid by Oliver (1991), who outlines five possible strategic responses to external expectation: acquiescence, compromise, avoidance, defiance, and manipulation. Building on this concept, efforts to gain, maintain or repair legitimacy are often broadly classified as either strategic, that is, oriented towards the manipulation of symbols and meaning structures, or institutional, 
oriented towards adapting to external expectations (Suchman, 1995). In transnational fields, however, there is no commonly shared, stable set of cultural or normative expectations that can serve as a reference point for established legitimation strategies. Instead, organizations and MNCs and their corporate elites in particular - seek to justify their practices and procedures through processes of moral reasoning with diverse stakeholders (Palazzo and Scherer 2006; Suchman 1995). Unlike manipulation tactics that are oriented towards imposing ones' view over others, Scherer and colleagues (2013) consider moral reasoning as an open-ended discursive process that involves learning and adaptation by incumbents and challengers alike. However, moral reasoning is often employed alongside adaptation and manipulation strategies, and the resulting patterns of legitimation strategies lack empirical elaboration to date.

Moral reasoning and emerging regulations also provide challengers with new options by which to question the corporate elites' legitimacy. For instance, sports manufacturers like Puma or Adidas have adapted to the new behavioral standard established by competitor Nike in increasing supply chain transparency, at the same time engaging in a stakeholder dialogue and trying to manipulate public perception with regard to environmental issues (Scherer et al., 2013). In one of the few existing studies examining sequences of interactions between corporations and challenging groups, Bartley (2003, 2007) finds that corporate responses to labor rights campaigns changed from the symbolic adoption of Codes of Conduct to the establishment of independent monitoring bodies in order to defend their legitimacy in the face of ongoing stakeholder pressure. Thus, transnational regulatory fields are like other fields a space of possibilities (cf. Bourdieu 1985: 737) for both corporate elites and challenging actors in which opportunity structures are created and enacted dynamically in specific actor constellations and with regard to specific regulatory issues. 


\section{Empirical Study: Regulating Labor Relations through Global Framework Agreements}

\subsection{Research Setting}

We draw on empirical data from a large, multi-country study of the emerging field of regulating transnational labor relations through Global Framework Agreements (GFAs) (Fichter et al. 2013a,b, 2012 a,b, 2011; Fichter \& Helfen, 2011; Fichter \& Stevis, 2013; Helfen \& Fichter, 2013; Helfen \& Sydow 2013; Helfen et al. 2012; Arruda et al. 2012; Gartenberg and Bandekar, 2011). ${ }^{1}$ The starting point of this research is that GFAs are signed between GUFs and MNCs to implement core ILO labor standards ${ }^{2}$ across MNCs' global operations, often including suppliers and joint ventures in the production network (Fichter et al., 2011). GFAs represent a form of regulation situated between voluntary standards (like corporate Codes of Conduct) and international law. They are distinct from accreditation and certification schemes in that they are based on institutionalized mechanisms of labor representation and interest aggregation (Kocher, 2008; Mund \& Priegnitz, 2007; Hammer 2005). For GUFs, GFAs provide an opportunity to influence global labor standards by bilateral, direct dealings with MNCs, as opposed to attempts to influence standards indirectly via the ILO whose conventions are directed at nation states and do not have MNCs as immediate addressees. GFAs thus promise a considerable, strategically important benefit for GUFs to contribute to the extension of industrial human rights, e.g. the right to form independent unions or the right to bargain collectively throughout MNCs’ global operations. Additionally, GUFs see GFAs as an opportunity for securing their own recognition as a

1 This work was supported by the Hans-Böckler-Foundation [grant number S-2008-141-2 B]. Additional support and technical assistance was provided by the Friedrich-Ebert-Foundation [no grant number].

2 The core labour standards refer to the prohibition of child labour (ILO co. 138 and 182) and forced labour (ILO co. 29 and 105), to non-discrimination and equal pay (ILO co. 100 and 111), and to freedom of association and collective bargaining (ILO co. 87 and 98). 
legitimate negotiation partner, since GFAs are, in many cases, the first instances in which MNC accept these union bodies as negotiating on behalf of employees (Fichter et al. 2013a).

The transnational business community, represented through bodies like the International Organization of Employers (IOE) or the European Roundtable of Industrialists (ERI), tends to disregard GFAs as an appropriate instrument through which to regulate labor relations. According to our interviews with representatives from these bodies, there is no consensus on supporting GFAs ideationally or actively. If individual MNCs sign a GFA, the issue is tolerated by way of taking a skeptical, but neutral stance. The vast majority of the approximately 80.000 MNCs (UNCTAD) have still not signed a GFA and thus, by and large, follow a strategy of voluntarism. MNCs for their part typically either do not perceive deficits in labor relations as an urgent issue, are entirely satisfied with a unilateral (CSR) approach, or are not convinced that GFAs bring a reliable solution for labor problems. Most MNCs follow a strategy of voluntary self-regulation in the form of Codes of Conduct, encompassing but not focusing on labor-related matters (Bartley, 2005). The corporate elite is in a favorable position in cross-border economic exchanges because social movement pressure by unions is weak, governments do not enforce workers' rights, and the transnational regulatory body (i.e. the ILO) lacks sanction-based enforcement mechanisms.

Nevertheless, a combination of reputation concerns due to high visibility in consumer markets, CSR policies, the tradition of cooperative labor relations at headquarters, and union pressure can increase the willingness of individual MNCs to sign a GFA (e.g. Helfen and Fichter, 2013; Helfen et al. 2012). The large majority of the 118 GFAs signed from the mid 1990s up until the end of 2013 have been negotiated with MNCs from continental Western Europe (21 Germany, 17 Scandinavia, 13 France, 12 Southern Europe, 9 Benelux), although the last five years have seen a slow increase in the number of agreements with MNCs whose headquarters are located in other parts of the world such as the USA, South Africa, Brazil, Japan, Canada, Indonesia, Australia and New Zealand (s. Table 1). 
Table 1: Global framework agreements, Dec 2013 (own compilation according to GUFs' webpages)

\begin{tabular}{|c|c|c|c|}
\hline $\begin{array}{l}\text { Global union } \\
\text { federations } \\
\left(\text { GUFs) }{ }^{* * *}\right)\end{array}$ & Sectors & $\begin{array}{l}\text { Total No. of GFAs } \\
\text { *) }\end{array}$ & $\begin{array}{l}\text { No. of GFAs with } \\
\text { non-European } \\
\text { MNCs }\end{array}$ \\
\hline IndustriAll****) & $\begin{array}{l}\text { Car manufacturing, } \\
\text { energy, chemical } \\
\text { industry, machine tool } \\
\text { \& metal engineering, } \\
\text { apparel and textiles }\end{array}$ & 43 & 5 \\
\hline UNI global union & $\begin{array}{l}\text { Telecommunication, } \\
\text { Retailing, Commerce, } \\
\text { Property and facility } \\
\text { services, Temporary } \\
\text { work agencies, printing } \\
\text { \& media, finance }\end{array}$ & $50 * *)$ & $\left.16^{* *}\right)$ \\
\hline BWI & $\begin{array}{c}\text { Construction and } \\
\text { building, building } \\
\text { materials, woodworking }\end{array}$ & 17 & - \\
\hline IUF & $\begin{array}{l}\text { Hotels \& catering, } \\
\text { food \& beverages }\end{array}$ & 8 & 3 \\
\hline Total & & 118 & 24 \\
\hline
\end{tabular}

Notes: ${ }^{*}$ ) as counted in terms of signing MNCs, $\left.{ }^{* *}\right)$ The total number of agreements within the domain of UNI is difficult to assess. UNI self-declares to have signed its 50th agreement in 2013. Due to various reasons, however, the actual number of GFAs is very likely to be lower. For example, many of the Non-European agreements have only a restricted geographical scope; mergers, acquisitions and liquidations have reduced the agreements still effective; some agreements lack in substantive jurisdiction; ***) the Public Service International has also been involved in negotiating GFAs, but always as a co-signatory to IndustriAll, ${ }^{* * *}$ ) containing all GFAs originally signed by IMF, ICEM and ITGWLF.

GFAs are company-specific, but are rooted in a wider transnational regulatory field in which nationally embedded and globally operating actor groups and networks struggle for influence on the employment policies and practices of MNCs. This "GFA arena" (Helfen \& Fichter, 2013: 556) is similar to other transnational regulatory fields in its multiple layers of regulation (Djelic and Quack, 2003; Djelic and Sahlin-Andersson, 2006; Djelic and Quack, 2010; Morgan \& Kristensen 2006): policy processes related to ILO standards, the presence of regional and national industrial relations institutions and legacies, and realities of company- 
level formal and informal regulations. In addition, the arena is marked by capital-labor antinomy (Helfen \& Fichter, 2013; Fichter et al., 2012b). On the labor side, works councils (European, world) are involved along with national affiliates and the GUFs. On the management side, involvement is usually from HR department heads, industrial relations experts, top management, and business associations on different levels.

Combined, the multi-lateral and multi-level nature of the GFA arena implies complex and heterogeneous actor constellations comprising (organized) labor and management actors at the transnational level (single MNCs and GUFs), national/sectoral level (national/sector unions and employer associations), MNC headquarter level in the home country, and at the level of local subsidiaries/suppliers in host countries. As a research setting, GFAs thus allow us to observe how corporate legitimation strategies are used and change in line with emerging regulations in a complex, multi-layered opportunity structure.

\subsection{Data Collection and Analysis}

For this paper, we take a bird's eye perspective on 28 case studies conducted by an international research team for GFAs in different GUF domains and in four different countries (Brazil, India, USA, Turkey) (e.g. Fichter et al., 2011; Fichter \& Helfen, 2011). We reinterpret and summarize this case study material through the lens of legitimation strategies of corporate elites faced with a moral reasoning challenge. We focus in depth on 12 case studies from manufacturing industries.

The original data collection effort between 2008 and 2011 included primary data (interviews with both parties of the agreements at the HQ level as well as with selected subsidiaries) and a host of secondary data (agreements themselves, interviews with third parties like employer associations and NGOs, companies' CSR and sustainability reports, and other documents containing general information about the cases). For the interview data, the aim was to have at least one interview per actor group and country for MNCs in the domains 
of four GUFs (now three due to the merger of ICEM, IMF and the ITGWLF to IndustriAll (2012)). Within this overall approach, the research team conducted well over 150 semistructured interviews (78 interviews with representatives of management and labor at the headquarter level and 68 interviews at corporate production sites in India, USA, Brazil and Turkey). Taken together, this data material allows us to capture varying perspectives, divergent assessments and common evaluations among the most relevant actors, above all, MNCs and GUFs across the transnational regulatory field in focus (Arruda et al. 2012; Fichter et al. 2011, 2012a, b; Fichter et al. 2013; Fichter and Stevis 2013; Helfen and Sydow 2013).

Out of all 28 MNCs, 22 already had a signed GFA during the field phase, one signed the GFA after the end of 2011, and five have not signed a GFA to date. The 12 cases we focus on in this paper are all in the domain of IndustriAll and BWI, actually have a GFA, and are empirically captured by at least one pair of interviews with management and labor representatives involved in the GFA process.

\section{Table 2: Interview material}

\begin{tabular}{lllll} 
GUF & Total Sample & Subsample & IndustriAll & BWI \\
No. of MNCs & 28 & 12 & 7 & 5 \\
\hline $\begin{array}{l}\text { Management } \\
\text { headquarter }\end{array}$ & 28 & 18 & 11 & 7 \\
$\begin{array}{l}\text { Unions } \\
\text { headquarter }\end{array}$ & 50 & 19 & 10 & 9 \\
$\begin{array}{l}\text { Management } \\
\text { local }\end{array}$ & 23 & 18 & 16 & 5 \\
Unions local & 45 & 22 & 17 & 5 \\
Sum & $\mathbf{1 4 6}$ & $\mathbf{8 0}$ & $\mathbf{5 4}$ & $\mathbf{2 6}$
\end{tabular}

Remaining gaps in the data collection process were filled either through secondary material or the growing literature on GFAs (e.g. Dehnen, 2013; Williams et al. 2013; Niforou 2011; Davies et al. 2011; Egels-Zandén 2009; Hammer 2005; for an extensive overview 
Papadakis 2011). For the secondary material, we draw on a text analysis of 73 GFAs (as of 2009). This analysis includes the 12 cases that examine core features of the formal agreements, such as parties' goals, the relationship between the parties, substantive content, scope, conflict resolution mechanisms, termination rules, and signatories. In addition, the research team examined numerous sources such as policy statements of global union federations and employer associations, internet pages and press releases.

In order to identify typical trajectories - historically rooted pathways resulting from repeated interactions (Malets \& Quack, 2013) - of how corporate elites respond to the moral reasoning challenge posed by GFAs, we draw on thick case descriptions and coding efforts developed in different stages of the original research process (see above) to derive an overall synthesizing picture for the subsample. We trace MNCs' trajectories from the initial proposal by the unions to sign a GFA, through to the preliminary management reaction, ensuing respective union responses and finally the subsequent managerial reaction. We have hereby applied the three types of corporate legitimation strategies distinguished by Scherer and colleagues (2013): moral reasoning, manipulation and adaptation. In presenting our results we abstract from details of single cases to provide an overview of managerial approaches to GFAs.

\section{Findings}

\subsection{Starting Conditions}

Although there are a few exceptions, the 'typical' successful GFA negotiation process unfolds as follows (s. also Helfen \& Sydow 2013): (1) the GUFs (more often than not supported and even led by national unions and works councils at the MNC headquarters) try to enter into negotiations with MNC management by applying various soft (and, rarely, strong) tactics; (2) management usually initially responds by declining the request on several grounds, but gives in and starts official negotiations if (3) the union side continues pushing for 
an agreement; (4) during negotiations management either continues to react with resilience through manipulation tactics or opens up a moral reasoning process depending on unions' bargaining position and concessions as well as on the management approach to labor relations. (5) Finally, an agreement is reached which then opens up the space for further (re)negotiations and debates as the implementation of the agreement is tested, evaluated, and monitored. From there on, a new iteration - somewhat equivalent to the starting phase - starts on a very different ground.

In all of our 12 cases, initiating GFA negotiations has been particularly difficult and demanding, since management and labor actors begin with very different perceptions about the need for global labor standards in the first place (Fichter et al. 2011). On the union side, a consent formation process is already required in that the GUFs convince their affiliates of the adequacy of a company-based policy process for dealing with violations of core ILO labor standards (see also Hammer, 2005; Papadakis, 2011; Croucher \& Cotton, 2009). On the level of individual MNCs, management reacted with tactics of defiance such as criticizing GFAs as a tool or claiming voluntary CSR initiatives to be sufficient in all but one of our cases. A change in managerial reluctance typically occurred only after several rounds of reiteration between the parties, somewhere between 6 months and several years.

\subsection{Typical Trajectories of Legitimation Strategies}

We can identify essentially three different trajectories of legitimation strategies across our sample of 12 MNCs: (1) a trajectory of responsibility-taking, in which MNCs adopt active measures to implement core labor standards across their supply chains (e.g. ChemCorp, documented in Helfen and Sydow, 2013; Fichter et al. 2011); (2) a trajectory of responsibility delegating and shifting, in which MNCs selectively respond to stakeholder demands (e.g. MetalCorp, documented in Helfen and Sydow, 2013; Helfen and Fichter 2013; Fichter et al. 2011); and (3) a trajectory of responsibility avoiding, in which there is a hollow agreement 
(Helfen and Sydow, 2013) followed by almost no active implementation activities (e.g.

ResourceCorp, documented in Helfen and Sydow, 2013; Fichter et al. 2011).

\section{Table 3: Classification of cases and outcomes}

\begin{tabular}{ll}
\hline Avoiding responsibility & $\begin{array}{l}\text { ResourceCorp, BWI, France } \\
\text { RubberCorp, IndustriAll, Germany } \\
\text { BuildCorp, BWI, Germany } \\
\text { MaterialCorp, IndustriAll, Germany }\end{array}$ \\
& $\begin{array}{l}\text { ConCorp, BWI, Scandinavia } \\
\text { Welegating and shifting } \\
\text { responsibility }\end{array}$ \\
& $\begin{array}{l}\text { FurnCorp, IndustriAll, Germany } \\
\text { CarCorp, IndustriAll, Germany } \\
\text { MetalCorp, IndustriAll, Germany } \\
\text { PapCorp, IndustriAll, Scandinavia }\end{array}$ \\
& \\
Taking responsibility & ChemCorp, IndustriAll, France \\
& PenCorp, BWI, Germany
\end{tabular}

These trajectories did not evolve in a linear way, but were carried forward by different situational opportunity structures and legitimation strategies on various levels. Table 3 places each of our cases within one of these three trajectories.

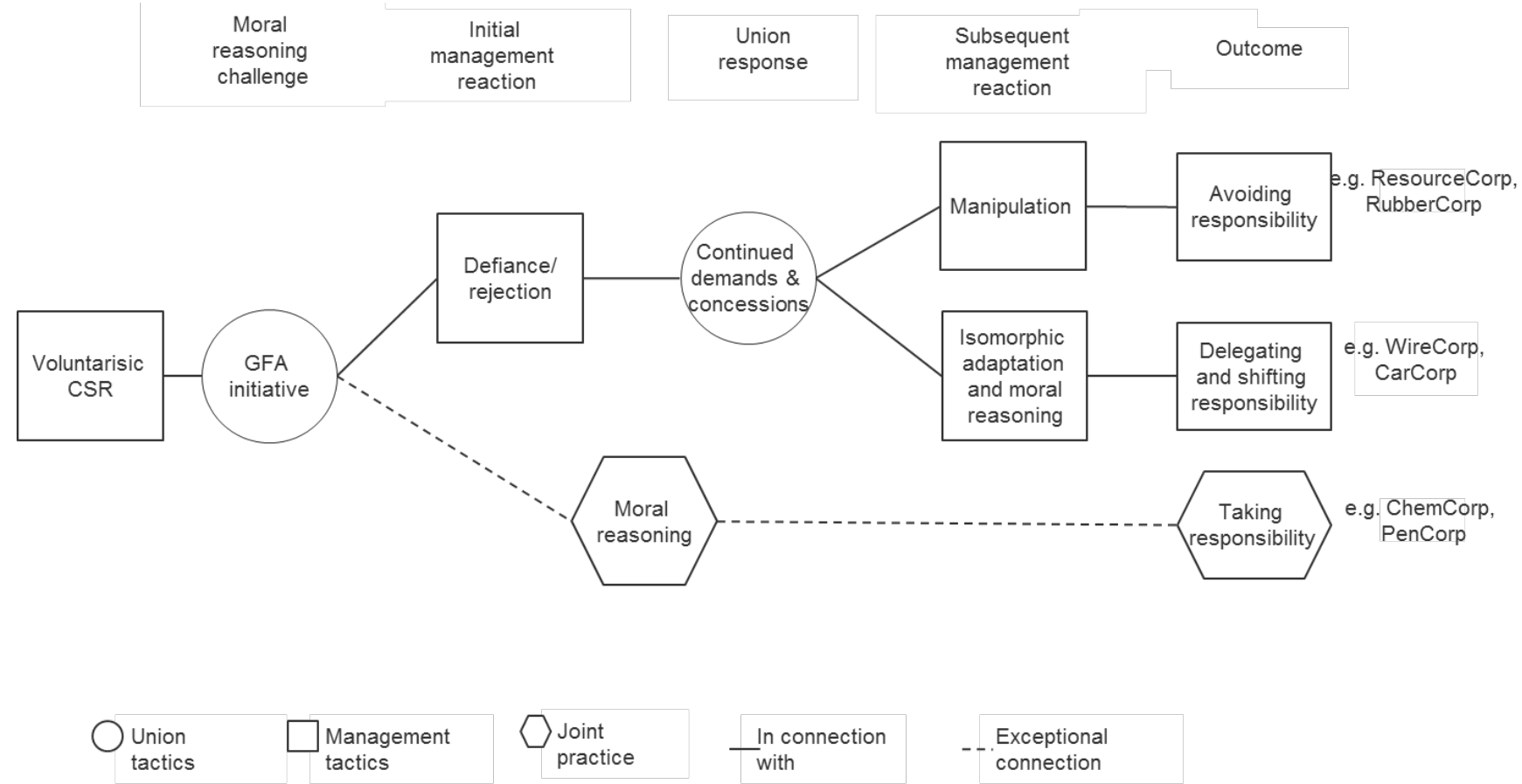

Figure 1: Trajectories of changes in legitimation strategies 


\title{
Delegating and shifting responsibility
}

The most common trajectory is the middle one in Figure 1, leading from initial management defiance towards engagement in moral reasoning with labor stakeholders, converting to selective adaptation of stakeholder demands and resulting finally in the delegation and shifting of responsibility where possible (6 MNCs). Here, the GFAs tend to outline specific implementation policies and escalation procedures, but exemplary good practices and initiatives in some areas are accompanied by passivity and neglect in others. For example, formalized mechanisms of monitoring and conflict resolution set up by MNCs might not be extended to all facilities. Swedish-based PapCorp is an exemplar of this phenomenon: the agreement's implementation is outstanding in one of its North American divisions, where an exceptional multi-plant collective agreement with the United Steelworkers has been signed, but implementation is weak in other business divisions and countries. For instance, in Colombia there appears to be a problem with PapCorp shifting responsibility for the agreement's implementation to the management team of a joint venture:

\begin{abstract}
"We have some problems sometimes, but we can't say that PapCorp is the primary trouble maker, because PapCorp is involved in joint ventures in different parts of the world, especially in Latin America, in a country like Colombia. And sometimes we get rumours, more or less, that maybe this joint venture company is not following (...). They don't accept the establishing of trade unions. But we have no proof, and we can't find people who want to come forward and say: 'I lost my job because I tried to organize a new trade union'." (PapCorp, union at headquarter)
\end{abstract}

As mentioned, good policies may also be thwarted by MNC passivity, as exemplified by German-based WireCorp. WireCorp is a relatively small MNC, but has a high number of global locations. As such, the European works council (with support from the union operating at WireCorp's headquarter) has been labor's leading agreement negotiator "in the spirit of constructive and co-operative conflict management" (WireCorp GFA). However, management has called the agreement a "joint declaration" and has insisted on its legally nonbinding character: 
"That is a declaration, but not an agreement, and it has been coordinated consensually with the EWC, but not negotiated." (WireCorp, headquarter management)

The works council responded to this with a concessionary bargaining style triggering some objections from the union at WireCorp's headquarter location:

"At WireCorp, we have a weak works council. And we have many non-unionized sites or sites with weak unions. Against this background one sometimes asks: 'Is it worth putting all that effort and energy into negotiating a GFA?'" (WireCorp, union at headquarter)

Nevertheless, the same union representative admits that complaint handling produces at least some results:

"(...) for example, we had reports from unions trying to organize at two locations in Romania. The unions tried to get in, but were blocked by local management. We put this issue on the table in the EWC meetings with central management. And finally, the local unions were able to organize these plants." (WireCorp, union at headquarter)

In fact, many German and Scandinavian MNEs follow this trajectory. In these countries, labor representation at the headquarters is strongly institutionalized and labor relations tend to be cooperative as state regulation is supportive of union rights strengthening the overall bargaining power of labor actors. In some cases, labor representatives are even co-opted into a position of co-management (see next section). In such cases, management initially tries to defy the GFA for the reasons mentioned above, but unions continue to exert pressure until, eventually, corporate elites engage in moral reasoning to accommodate and pacify external demands interactively.

\section{Avoiding responsibility}

The second most common trajectory is one that leads from defiance towards the use of manipulation strategies, resulting ultimately in avoidance of responsibility (4 MNEs). Essentially, management in these cases strategically drafts a GFA with the aim of avoiding 
open opposition, but uses various manipulation tactics to avoid an actual change in behavior. For example, we find cases in which management successfully restricted the scope of the agreements by declaring direct control of operations as a necessary precondition, directly excluding joint ventures, majority and minority investments and sub-contractors. In such cases, the GFA is not typically integrated in an MNC's sourcing policy and no responsibility is taken for (deviant) partners in business relationships (e.g. ResourceCorp, BuildCorp). Furthermore, management often manipulated the scope of an agreement by defining local customs and regulations as a restricting condition. This approach is well illustrated in the case of ResourceCorp (cf. Helfen and Sydow, 2013):

"It is not our responsibility to operate our sub-contractors. We are not to interfere with the business management of our sub-contractors or either it won't be sub-contracting but ResourceCorp." (ResourceCorp, headquarter management 1)

In other cases, the procedure of complaint handling is underspecified, ad hoc, and informal. This shifts the burden of proof of violations to the unions and opens up leeway for postponing the resolution of problems that emerge. Where neither a formal procedure nor clear-cut organizational accountability for the GFA is defined, the agreement cannot be put into practice locally without difficulty.

Strategic manipulation by corporate elites provides the basis for a weak agreement that delegates responsibility. One path in this direction may be a headquarter-level social partnership in which labor representatives are co-opted as co-managers and the management effectively only negotiates with these representatives (e.g., worker representatives on the supervisory board or works councils) thereby excluding labor actors like GUFs' local affiliates, which might be more sensitive to local problems (e.g. BuildCorp). Another manipulation tactic is a paternalistic strategy typical for family-owned firms that claim responsibility for their own actions and neutralize critique by emphasizing how needs are taken care of by a traditional distribution of rights and responsibilities (e.g. ResourceCorp, 
RubberCorp). In such cases, the management approach to independent labor representation is characterized by adversarialism, even if mechanisms of labor voice are strongly institutionalized at the headquarters' location as in countries such as Germany or France. Manipulation tactics such as deploying disunity among labor actors or inadequately informing, communicating, and educating subsidiary managers on the contents of the GFA allow corporate elites to maintain internal processes in their extant form in this trajectory. Management signals compliance through the guise of a formal GFA, but shields core activities from external evaluation. By not refusing the GFA, corporate elites establish themselves symbolically as the legitimate actor to influence, control, or monitor the regulation of corporate activities, but effectively circumvent the moral reasoning challenge.

\section{Taking responsibility}

A much more unusual trajectory is that of direct engagement in a moral reasoning process when faced with a GFA, resulting in a strong agreement and actual behavior change. A good illustration for a trajectory marked by high cooperation in legitimation strategies is that of French ChemCorp in the domain of IndustriAll. Here, the initiative to sign a GFA is actually a joint activity by management and unions, because management seeks to increase its responsibility with regard to CSR issues (Fichter et al. 2011). In this case, we can say that management has long engaged in moral reasoning with employee representatives and has developed a highly collaborative labor relations culture at the headquarters characterized by strong unions. Also, the German PenCorp in the domain of the BWI is a good example of a responsibility-taking trajectory. In contrast to ChemCorp, PenCorp is a committed familyowned company that takes responsibility for its global production as the following quote illustrates:

"There are many firms having a voluntary Code of Conduct, but usually without any external control. For me, the tendency is clear that external ratification and control is the future. And CSR must not be allowed to be a mere 'strategy', for PR or marketing. We 
need to face the issue head on. From the start, CSR must be top-down in the sense that the CEO, the company's leadership takes the issue to heart, otherwise it simply does not work." (PenCorp, headquarter management)

In both cases management has positively and constructively reacted to a union initiative for a GFA. In the case of PenCorp, well-organized labor representatives reviewed production sites across the world and reported that some sites in Brazil and Asia have very high social standards. Upon this report, the suggestion to improve the situation for all production sites based on the ILO-standards was immediately welcomed by management.

\subsection{Opportunity Structures for Different Trajectories}

These trajectories are influenced by the ways in which contesting actors enacted their institutional environments, relationships, or symbolic resources in the political struggle. Most GFAs to date are European, so the institutionally embedded tradition of employee participation and representation at the country of the headquarter location is an important factor for getting MNCs to the negotiation table. Specifically, continental European MNEs like Scandinavian, German, or French MNCs have been more likely to negotiate GFAs than Anglo-Saxon or Southern European MNCs so far, not to mention MNCs from the Americas or Asia. At the same time, there are important differences between the strategies of GFAsigning MNCs from the same country, so this institutional background does not automatically precondition a certain kind of trajectory. Rather, the way labor actors use their institutionally granted power resources in specific interactions at the MNC headquarters can effect change in legitimation strategies.

Forming and upholding unity among the various labor actors seeking involvement in the GFA process both on the national and transnational level was important for limiting the scope for manipulation. Again, this condition is not static, but develops in the context of specific interactions and actor constellations. 
Within the interaction process, unions typically had to accept the dominant influence of MNC headquarter management. They did so through discursive position-taking exemplified by consciously excluding controversial substantive issues like global differentials in wages and material working conditions, even though these were important for explaining unions' motivations to have a GFA in the first place. Similarly, the issue of how to finance implementation was also taken out of negotiations. Such contested issues would have fuelled the fears of their management counterparts about the potential risks of GFAs as a new regulatory instrument. In turn, concessions from the union side made it easier for corporate elites to change their initial resistance, but also opened many doors for opportunistic behavior, most importantly by manipulating agreements' jurisdictions and decoupling the stated intentions from actual behavior.

The final test of the credibility of corporate elites occurs when violations of the agreement are brought to headquarter-level review meetings for discussion. Our evidence indicates that headquarter unions already leading the labor camp at the GFA negotiation stage are also capable of taking up controversial issues and bringing them to the table for effective resolution of later-stage violations, although a more longitudinal perspective is necessary to differentiate structural from situational factors in this observation.

\section{Discussion and Conclusions}

We have set out to examine changes in the legitimation strategies corporate elites use in response to challenges from societal actors in the field of transnational labor regulation. An analysis of different trajectories of legitimation allows us to elaborate on the combination of strategies and their variability over time. We hereby go beyond existing approaches that study how organizations, and in particular the management of large corporations, deal with conflicting institutional demands (e.g. Greenwood et al., 2011; Pache and Santos, 2010). More concretely, we compare how different MNCs respond to one moral reasoning challenge 
- here, the request to sign a GFA and implement ILO core labor standards across global operations - and the resulting interactions. We have identified three 'typical' trajectories of changes in legitimation strategies carried forward by the enactment of relational and institutional opportunity structures in sequences of interactions between elites and challenging groups.

Applying the conceptual framework of corporate legitimation strategies developed by Scherer and colleagues (2013) we suggest several refinements. First, we observe that in the case of GFAs the initial choice and change of legitimation strategies depends less on the calculated cost of required organizational change or the heterogeneity of demands exhibited by different actors operating within divergent institutional environments, and more on the extent to which challenger groups - trade unions, their confederative bodies, advocacy and charity NGOs, local governments, national policy agencies, and international organizations are able to collaboratively hold corporate elites accountable across institutional distances (Kostova, 1999). The lack of transnational union collaboration, for instance, was a clear prerequisite for corporate voluntarism or manipulation in countries with weak industrial relations institutions. Generally, the slowly growing, but still very limited spread of GFAs as a regulatory instrument can be attributed to a lack of resources, unclear communication channels, and political or ideological disagreements among the various actors from the labor side, which make such a transnational union collaboration difficult to form in the first place (for a general treatment, see Anner, 2009). On a global level, GUFs are relatively small organizations compared to MNCs. On a national level, the influence of labor actors at MNC headquarters varies strongly between countries, sectors, and even individual companies. Such variations provide the background against which interactions between corporate elites and challenging actors unfold - and influence the extent to which the GFA process is open to corporate maneuvering. 
Given this situation, the few cases where GFAs led to a profound strategy change from voluntarism to responsibility-taking can be attributed less to the powerful, united counterforce exhibited by trade unions, and more to a preexisting receptivity of corporate elites to collaborate with unions on issues such as good labor practices. The much more common scenario, however, is that corporate elites de facto avoid engaging in a moral reasoning process by symbolically adopting a GFA that is weak and unspecific so that ultimately they are not held accountable for poor labor standards. Thus, second, we conclude that the propensity for the efficacy of a moral reasoning strategy regarding sustainability issues may be overestimated by Scherer and colleagues (Palazzo and Scherer, 2006; Scherer et al., 2013). By being able to shape the 'material' content of regulations (i.e. in our case GFAs) in the process of bargaining with labor representatives, corporate elites can combine a discursive, moral reasoning process with a selective adaptation towards norms emerging collectively within a certain sector. Legitimacy remains important even in cases when management applies manipulation tactics such as restricting the scope of the agreement or leaving implementation measures unspecified and avoiding moral reasoning altogether. Which strategy is chosen depends strongly on the history of labor relations in particular MNCs embedded in particular sectors and countries.

Third, the existence of heterogeneous demands for sustainability highlighted by Scherer and colleagues (2013) not only constitutes a challenge to, but also a resource for corporate elites. The existence of alternative regulatory instruments such as voluntary Codes of Conduct, for instance, allow many MNCs to avoid engaging in a GFA process altogether. Thus, the more regulatory arenas are opened up and regime complexity increases (Quack, 2013), the more corporate elites can play different initiatives and stakeholder groups against each other so as to defend their legitimacy by symbolically adapting to some demands, while declaring that others are unjustified. Such strategies are particularly relevant in legally ambiguous regulatory fields around the "fictitious commodities" of land, labor and money 
(Polyani, 1944) where implementation into national politics is typically weak or heterogeneous and interactions among elites and challenger groups form in multiple arenas and around multiple regulatory issues (e.g. Keophae and Victor, 2011).

GFAs`effectiveness depends heavily on enforcement, which in turn is influenced by the endurance of countervailing social groups on both national and transnational levels. In our study, the variability of corporate legitimation strategies points to a forceful legacy of national arenas and issue fields in which "old" legitimation strategies such as manipulation and decoupling are still effective - unless challenger groups find opportunities to mobilize a collective stakeholder effort on the transnational level that actually puts elites "on trial.”

Given that such transnational coordination among challenger groups is required to create mutually reinforcing pressure on corporate elites from "above" and "below" (Keck and Sikking, 1998), further research is needed to analyze conflicts in anti-corporate mobilization (cf. Kraemer et al., 2013). Further research and models on legitimation strategies should also take different levels of analysis more decidedly into account. In particular, the sectoral level on which norms and practices converge cross-nationally seems to be highly relevant as a unit of analysis. While we expect that legitimation strategies dynamically change through interaction with challenger groups also in other transnational regulatory fields such as the global trade regime forming around the WTO, the trajectories may be different depending on the strength of enforcement mechanisms behind regulations, the legal ambiguity of regulations or regime complexity, and the patterns of coordination and collaboration among challenging groups nationally and transnationally.

Scherer and colleagues (2013) raise the question of how long manipulation strategies are sustainable. In our case, ongoing stakeholder pressure may well cause another shift in the legitimation strategy of corporate elites that are currently on a "weak" trajectory sustained through manipulation. Finally, it must be recognized that corporate elites are willing to risk 
being perceived as illegitimate and, in some instances, use non-legitimate, non-legal instruments and other instruments from the sphere of direct force and domination.

\section{References}

Aldrich, H. E., \& Fiol, C. M. (1994). Fools rush in? The institutional context of industry creation. Academy of Management Review, 19(4), 645-670.

Ashforth, B. E., \& Gibbs, B. W. (1990). The double-edge of organizational legitimation. Organization Science, 1(2), 177-194.

Anner, M. (2009). Two Logics of Labor Organizing in the Global Apparel Industry. International Studies Quarterly, 53, 545-570.

Arruda, L., Fichter, M., Helfen, M. \& Sydow, J. (2012) International Framework Agreements - a powerful tool for ensuring Core Labor Standards in a globalized world? Insights from Brazil. Sao Paulo / Berlin: Friedrich-Ebert-Foundation.

Barley, S. R. (2010). Building an institutional field to corral a government: A case to set an agenda for organization studies. Organization Studies, 31, 777-805.

Barley, S. R. (2007). Corporations, democracy, and the public good. Journal of Management Inquiry, 16, 201-215.

Bartley, T. (2007). Institutional emergence in an era of globalization: The rise of transnational private regulation of labor and environmental conditions. American Journal of Sociology, 113(2), 297-351.

Bartley, T. (2005). Corporate accountability and the privatization of labor standards: Struggles over codes of conduct in the apparel industry. Research in Political Sociology, $14,211-244$.

Bartley, T. (2003). Certifying Forests and Factories: States, Social Movements, and the Rise of Private Regulation in the Apparel and Forest Products Fields. Politics \& Society, 31(3), 433-464.

Bernstein, S. (2011). Legitimacy in intergovernmental and non-state global governance. Review of International Political Economy, 18(1), 17-51.

Botzem, S., \& Hofmann, J. (2010). Transnational governance spirals: the transformation of rule-making authority in Internet regulation and corporate financial reporting. Critical Policy Studies, 4(1), 18-37.

Bourdieu, P. (1985). The social space and the genesis of groups. Theory and Society, 14, 723744. 
Braverman, H. (1998) Labor and Monopoly Capital: The Degradation of Work in the Twentieth Century. New York, NY: Monthly Review Press [1974].

Buroway, M. (1979) Manufacturing Consent: Changes in the Labor Process under Monopoly Capitalism. Chicago, IL: Chicago University Press.

Carroll, W. K. (2009). Transnationalists and national networkers in the global corporate elite. Global Networks, 9(3), 289-314.

Carroll, W. K., \& Sapinski, J. P. (2010). The Global Corporate Elite and the Transnational Policy-Planning Network, 1996-2006 A Structural Analysis. International Sociology, 25(4), 501-538.

Davis, G. F. (1991). Agents without principles? The spread of the poison pill through the intercorporate network. Administrative Science Quarterly, 36(4), 583-613.

Davis, G. F., \& Greve, H. R. (1997). Corporate elite networks and governance changes in the 1980s. American Journal of Sociology, 103(1), 1-37.

Davis, G. F., \& Mizruchi, M. S. (1999). The money center cannot hold: Commercial banks in the US system of corporate governance. Administrative Science Quarterly, 44(2), 215-239.

Davies, S., Hammer, N., Williams, G., Raman, R., Ruppert, C. S. and Volynets, L. (2011). 'Labour standards and capacity in global subcontracting chains: Evidence from a construction MNE’. Industrial Relations, 42, 124-38.

Davies, S., Williams, G., \& Hammer, N. (2011). Organizing Networks and alliances: International unionism between the local and the global, In: Papadakis, K. (ed.): Shaping global industrial relations. The impact of International Framework Agreements. (pp. 201219). Geneva/London: ILO/Palgrave.

Dehnen, V. (2013): Transnational Alliances for Negotiating International Framework Agreements: Power Relations and Bargaining processes between Global Union Federations and European Works Councils. British Journal of Industrial Relations, 51(3): 577-600.

Dezalay, Y., \& Garth, B. (2010). Marketing and selling transnational 'judges’ and global 'experts': building the credibility of (quasi)judicial regulation. Socio-Economic Review, 8(1), 113-30.

DiMaggio, P., \& Powell, W. W. (1991). Introduction. In W. W. Powell \& P. DiMaggio (Eds.), The New Institutionalism in Organizational Analysis (pp. 1-38). Chicago: The University of Chicago Press.

Djelic, M-L., \& Quack, S. (Eds). (2003). Globalization and Institutions. Redefining the Rules of the Economic Game. Cheltenham: Edward Elgar: 
Djelic, M.-L., \& Quack, S. (2008). Institutions and transnationalization. In R. Greenwood, C. Oliver, R. Suddaby \& K. Sahlin-Andersson (Eds.), Sage Handbook of Organizational Institutionalism (pp. 299-323). London: Sage.

Djelic, M-L., \& Quack, S. (Eds). (2010). Transnational Communities. Shaping Global Economic Governance. Cambridge.

Djelic, M-L., \& Sahlin-Andersson, K. (Eds.). (2006). Transnational Governance: Institutional Dynamics of Regulation. Cambridge: Cambridge University Press.

Egels-Zandén, N. (2009). TNC motives for signing International Framework Agreements: A continuous bargaining model of stakeholder pressure. Journal of Business Ethics, 84, 529547.

Erkama, N., \& Vaara, E. (2010). Struggles over legitimacy in global organizational restructuring: A rhetorical perspective on legitimation strategies and dynamics in a shutdown case. Organization Studies, 31(7), 813-839.

Fichter, M., \& Helfen, M. (2011). Going local with global policies: Implementing International Framework Agreements in Brazil and the United States, in: Papadakis, K. (Hrsg): Shaping Global Industrial Relations. The Impact of International Framework Agreements (pp. 85-115). Geneva/London: ILO/Palgrave .

Fichter, M., Helfen, M., \& Sydow, J. (2011). Employment relations in global production networks - Initiating transfer of practices via union involvement. Human Relations, 64 (4), 599-624.

Fichter, M., Helfen, M., \& Schiederig, K. (2013a). Transnational Solidarity around Global Production Networks? Reflections on the Strategy of International Framework Agreements. in: P. Fairbrother, M.-A. Hennebert \& C. Levesque (eds.) Transnational Trade Unionism. Building Union Power (pp. 203-222). New York: Routledge.

Fichter M, Sayim KZ \& Agtas ÖB (2013b) Oganization and Regulation of Empoyment Relations in Transnational Production and Supply Networks. Ensuring Core Labor Standards through International Framework Agreements? Ankara: Friedrich-EbertFoundation. http://www.festuerkei.org/media/pdf/Partnerpublikationen/layouts\%20web\%20english.pdf.

Fichter, M., Sydow, J., Helfen, M., Arruda, L., Agtas, Ö.B., Gartenberg, I., McCallum, J.K., Sayim, K.Z. \& Stevis, D. (2012a): Globalising Labour Relations. On Track with Framework Agreements? Berlin: Friedrich-Ebert-Foundation. http://library.fes.de/pdffiles/iez/09422-20121129.pdf.

Fichter, M. \& Stevis, D (2013) Global framework agreements in a union-hostile environment: the case of the USA. Berlin: Friedrich-Ebert-Stiftung. http://library.fes.de/pdffiles/id/10377.pdf. 
Fichter, M., Stevis, D., \& Helfen, M. (2012b): Bargaining for corporate responsibility: The global and the local of framework agreements in the USA, in: Business and Politics 14(3): 1-31, DOI: 10.1515/bap-2012-0017.

Fligstein, N. \& McAdam, D. (2012). A Theory of Fields. Oxford University Press.

Gartenberg, I., \& Bandekar, S. (2011): Challenges to ensuring core labour standards in transnational corporations: The case of India, The Indian Journal of Labour Economics 54(2): 269-283.

Greenwood, R., Raynard, M., Kodeih, F., Micelotta, E. R., \& Lounsbury, M. (2011). Institutional complexity and organizational responses. The Academy of Management Annals, 5(1), 317-371.

Hammer, N. (2005). International Framework Agreements: Global industrial relations between rights and bargaining. Transfer, 11, 511-530.

Harvey, C., \& Maclean, M. (2010). Transnational boards and governance regimes: A FrancoBritish comparison. In M.-L. Djelic \& S. Quack (Eds.), Transnational Communities. Shaping Global Economic Governance (pp. 107-129). Cambridge: Cambridge University Press.

Helfen, M. \& Fichter, M. (2013): Building Transnational Union Networks across Global Production Networks: Conceptualising a New Arena of Labour-Management Relations, in: British Journal of Industrial Relations 51(3): 553-576.

Helfen, M., Fichter, M. \& Sydow, J. (2012): Anfänge einer Institutionalisierung grenzüberschreitender Arbeitsbeziehungen? Zur Paradoxie der Internationalen Rahmenabkommen im globalen Dienstleistungssektor, in: Industrielle Beziehungen 19(3): 290-313.

Helfen, M. \& Sydow, J. (2013): Negotiating as institutional work: The case of labour standards and international framework agreements, in: Organization Studies 34(8): 10731098.

Hensmans, M. (2003). Social movement organizations: A metaphor for strategic actors in institutional fields. Organization Studies, 24(3), 355-381.

Hoffman, A. (1999). Institutional evolution and change: Environmentalism and the U.S. chemical industry. Academy of Management Journal, 42(4), 351-371.

Keck, M. \& Sikkink, K. (1998) Activists Beyond Borders: Advocacy Networks in International Politics. Ithaca: Cornell University Press.

Robert O. Keohane and David G. Victor (2011). The regime complex for climate change. Perspectives on Politics, 9(1), 7-23.

Kerr, R., \& Robinson, S. (2012). From symbolic violence to economic violence: the globalizing of the Scottish Banking elite. Organization Studies, 33(2), 247-266. 
Khaire, M. (2010). Young and No Money? Never Mind: The Material Impact of Social Resources on New Venture Growth. Organization Science, 21(1), 168-185.

King, B. G. (2008). A political mediation model of corporate response to social movement activism. Administrative Science Quarterly, 53(3), 395-421.

Kocher, E. (2008). Codes of Conduct and Framework Agreements on Social Minimum Standards - Private Regulation?, In: Dilling, O., M. Herberg, and G. Winter (eds): Responsible Business: Self-Governance and Law in Transnational Economic Transaction (pp. 67-86.). Oxford and Portland.

Kostova, T., \& Zaheer, S. (1999). Organizational legitimacy under conditions of complexity: The case of the multinational enterprise. Academy of Management Review, 24(1), 64-81.

Kraemer, R., Whiteman, G., \& Banerjee, B. (2013). Conflict and astroturfing in Niyamgiri: The importance of national advocacy networks in anti-corporate social movements. Organization Studies, 34(5-6), 823-852.

Lawrence, T. B. (2008). Power, Institutions and Organizations. In R. Greenwood, C. Oliver, R. Suddaby and K. Sahlin (Eds.), The Sage Handbook of Organizational Institutionalism (pp. 170-197). London: Sage.

Levy, D. L. (2008). Political contestation in global production networks. Academy of Management Review, 33, 943-963.

Lounsbury, M., Ventresca, M., \& Hirsch, P. M. (2003). Social movements, field frames and industry emergence: a cultural-political perspective on US recycling. Socio-Economic Review, 1(1), 71-104.

Malets, O. \& Quack, S. (2013): Projecting the Local into the Global: Trajectories of Participation in Transnational Standard-setting. In: Drori, G., Höllerer, M. \& Walgenbach, P. (Eds.): Global Themes and Local Variations in Organization and Management. Perspectives on Glocalization (pp. 325-338). London: Routledge.

Mayntz, R. (2012). Institutional Change in the Regulation of Financial Markets: Questions and Answers. In: Crisis and Control. Institutional Change in Financial Market Regulation. Frankfurt/M.: Campus, 7-27

McAdam, D., \& Scott, R. W. (2005). Organizations and movements. In G. F. Davis, D. McAdam, R. Scott and M. N. Zald (Eds.), Social Movements and Organization Theory (pp. 4-40). New York: Cambridge University Press.

Mills, C. W. (2000/1956). The Power Elite. New York: Oxford University Press.

Mizruchi, M. S. (2004). Berle and Means revisited: the governance and power of large U.S. corporations. Theory and Society, 33, 579-617.

Morgan, G., \& Kristensen, P. H. (2006). The contested space of multinationals: Varieties of institutionalism, varieties of capitalism, Human Relations, 59, 1467-1490. 
Mund, H., \& Priegnitz, K.( 2007). Soft law - second best solution or a privatisation of social rights? Some pointers for a future discussion, Transfer, 13, 671-677.

Niforou, C. (2011). 'International framework agreements and industrial relations governance: Global rhetoric versus local realities’. British Journal of Industrial Relations, 50, 352-73.

Oliver, C. (1991). Strategic responses to institutional processes. Academy of Management Review, 16, 145-179.

Overdevest, C. (2010). Comparing forest certification schemes: the case of ratcheting standards in the forest sector. Socio-Economic Review, 8(1), 47-76.

Pache, A. C., \& Santos, F. (2010). When worlds collide: The internal dynamics of organizational responses to conflicting institutional demands. Academy of Management Review, 35(3), 455-476.

Palazzo, G., \& Scherer, A. G. (2006). Corporate Legitimacy as Deliberation: A Communicative Framework. Journal of Business Ethics, 66(1), 71-88.

Papadakis, K. (ed.) (2011): Shaping Global Industrial Relations. The Impact of International Framework Agreements. Geneva/London: ILO/Palgrave.

Pfeffer, J., \& Salancik, G. R. (2003). 1978. The External Control of Organizations: A Resource Dependence Perspective. Stanford: Stanford University Press.

Polanyi, K. (1944). The Great Transformation: The Political and Economic Origins of Our Time. Beacon Press.

Quack, S. (2010). Law, Expertise and Legitimacy in Transnational Economic Governance: An Introduction. Socio-Economic Review, 8, 3-16.

Quack, S. (2013). Regime Complexity and Expertise in Transnational Governance: Strategizing in the Face of Regulatory Uncertainty. Oñati Socio-Legal Series, 3(4), 647678.

Scherer, A. G., \& Palazzo, G. (2011). The New Political Role of Business in a Globalized World: A Review of a New Perspective on CSR and its Implications for the Firm, Governance, and Democracy. Journal of Management Studies, 48(4), 899-931.

Scherer, A. G., Palazzo, G., \& Seidl, D. (2013). Managing legitimacy in complex and heterogeneous environments: Sustainable development in a globalized world. Journal of Management Studies, 50(2), 259-284.

Schüßler, E., Rüling, C., \& Wittneben, B. (2014). On melting summits: The limitations of field-configuring events as catalysts of change in transnational climate policy. Academy of Management Journal, 57, 140-171.

Strike, V. M., Gao, J., \& Bansal, P. (2006). Being good while being bad: Social responsibility and the international diversification of US firms. Journal of International Business Studies, 37(6), 850-862. 
Suchman, M. S. (1995). Managing legitimacy: Strategic and institutional approaches. Academy of Management Review, 30, 571-610.

Suddaby, R., \& Greenwood, R. (2005). Rhetorical strategies of legitimacy. Administrative Science Quarterly, 50, 35-67.

Suddaby, R., Cooper, D. J., \& Greenwood, R. (2007). Transnational regulation of professional services: Governance dynamics of field level organizational change. Accounting, Organizations and Society, 32(4), 333-362.

Useem, M. (1984). The inner circle: Large corporations and the rise of business political activity in the US and UK. Oxford University Press.

Vaara, E., Tienari, J., \& Laurila, J. (2006). Pulp and paper fiction: On the discursive legitimation of global industrial restructuring. Organization Studies, 27, 789-810.

Waddock, S. (2008). Building a new institutional infrastructure for corporate responsibility. Academy of Management Perspectives, 22, 87-108.

Williams, G., Davies, S., and Chinguno, C. (2013): Subcontracting and Labour Standards: Reassessing the Potential of International Framework Agreements. British Journal of Industrial Relations, doi: 10.1111/bjir.12011.

Zald, M. N., \& Lounsbury, M. (2010). The Wizards of Oz: Towards an Institutional Approach to Elites, Expertise and Command Posts. Organization Studies, 31, 963-996.

Zürn, M. (2004). Global governance and legitimacy problems. Government and Opposition, 39(2), 260-287. 